\title{
PSYCHE
}

VoL. 56

JUNE, 1949

No. 2

\section{ON A SMALL COLLECTION OF FULGOROIDEA (HOMOPTERA) FROM THE VIRGIN ISLANDS ${ }^{1}$}

By R. G. Fennah

Entomologist, Food-crop Pests Investigation, Windward and Leeward Islands

The Virgin Islands, which lie between $18^{\circ} 55$ N. $64^{\circ} 10$ $\mathrm{W}$. and $18^{\circ} 25 \mathrm{~N} .65^{\circ} 00 \mathrm{~W}$., are the eastern outliers of the Greater Antilles. St. Thomas, the westernmost, is separated by a channel 30 miles wide from Culebra, off Puerto Rico, while St. John is 70 miles from the St. Barts group to the south. St. Croix, though politically grouped with the Virgin Islands, is not considered here as it stands apart from the chain of islands between St. Thomas and Anegada.

The natural vegetation of these islands consists to an overwhelming extent of dry scrub. At the summit of the highest points occur small patches of woodland with the characteristics of true mountain forest.

As far as Fulgoroidea are concerned, the affinities of the fauna are unquestionably with that of Puerto Rico, and it would seem (in the absence of collections from the St. Barts group) that the islands represent the furthermost limit of some of the Greater Antillean species. Of the species discussed below Bothriocera eborea Fenn. and Sogata furcifera (Horv.) are the only two which range southward through the Leeward and Windward Islands: Oliarus campestris Fenn., Petrusa marginata

1 Published with a grant from the Museum of Comparative Zoology at Harvard College. 
(Brunn.) and Melormenis quadripunctata (F.) occur in the Greater Antilles and in the Leeward Islands (Antigua, St. Kitts, Nevis, Montserrat) but not in the Windward Islands; Cubana tortriciformis Muir is represented in the Lesser Antilles by very close geographical equivalents grouped around the St. Vincent Cubana tortrix Uhl.; Neurotmeta occurs as far south as Dominica; Oliarus campestris is very clearly replaced in the Windward Islands and Trinidad by O. maidis Fenn. The group of species or subspecies closely resembling Acanalonia depressa $\mathrm{Mel}$. has no representatives in the Lesser Antilles, while the Thionia described below is not very close to any Lesser Antillean species. The genera Ladella, Remosa, and Tangella and the flatid Parthenormenis described below do not occur in the Lesser Antilles and have no obvious equivalents there, though by contrast the forestdwelling Chasmacephala of the Windward Islands clearly shares a common ancestry with the Greater Antillean Parahydriena and Cyphoceratops.

In so small a collection little significance can be attached to the absence of species but, in view of their abundance in the Leeward Islands as far north as Anguilla, the writer would have expected to find a species of Ilesia among the flatids of the littoral zone. The genus Antillormenis does not reach northward of the Leeward Islands and even here occurs only in Montserrat.

\section{Ciximde Cubana Uhler}

Uhler 1895 Proc. Zool. Soc. Lond.: 62. Haplotype, Cubana tortrix Uhler loc. cit.: 62.

\section{Cubana tortriciformis Muir}

Muir 1924 Proc. Haw. Ent. Soc. 5, 3: 461.

A single female taken by the writer at Road Town, Tortola (Feb. 25, 1944) is assigned to this species. The specimen differs from the type of $C$. tortrix only in having the distal fuscous line in the tegminal membrane overlying cell R2 and the large spot basad of it biconcave on its inner face. It is probable that Pintalia alta Osborn is this species. 
Oliarus (Melanoliarus) Fenn.

Fennah 1945 Proc. Biol. Soc. Wash. 58: 141. Subgenotype, Oliarus maidis Fenn. 1945 Proc. U. S. Nat. Mus. $95: 423$.

Oliarus (Melanoliarus) campestris Fenn.

Fennah 1945 loc. cit.: 141.

One male was taken by the writer on Jost Van Dyke (Feb. 18, 1944). In this subgenus of Oliarus each ovary comprises sixteen ovarioles. In the closely allied genus $V i n c e n t i a$ each ovary has eighteen ovarioles.

\section{Bothriocera Burm.}

Burmeister 1835 Handbuch der Entomologie: 156. Haplotype, Bothriocera tinealis Burmeister loc. cit.: 156.

Bothriocera eborea Fenn.

Fennah 1943 Psyche 52: 14.

Three males and four females were taken by the writer on Jost Van Dyke on Coccoloba uvifera (Feb. 18, 1944), and two males and eight females on Tortola (Feb. 15$17,1944)$.

Delphacidat Sogata Distant

Distant 1906 F. B. I. $3: 471$. Orthotype, Sogata dohertyi Distant loc. cit.: 471 .

Sogata furcifera (Horv.)

Delphax furcifer Horvath 1899 Term. Fuz. 22: 372.

One male taken by the writer at Road Town, Tortola (Feb. 14, 1944). This generic assignment is merely provisional pending revision of the family.

\section{TROPIDUCHIDA}

The tropiduchid fauna of Central America and the West Indies is rich in genera and nomenclatorial confusion has arisen as a result of changed conceptions of generic limits. In his classification of the family Melichar accorded tribal status to genera in which a costal area with transverse veinlets is present in the tegmina; genera within this group characterised by marked elonga- 
tion of the vertex were separated as a further tribe (Peggiogini). These tribal characters are not rigorous in their application, but intergrade with those found in the Tambiniini both in West Indian and Australasian genera. The development of a costal area, for example, may vary within a single genus. The South American Rotunosa indicanda (Wlk.) has a narrow costal area with distinct transverse veinlets in the distal part of the corium; nearer the base the costal area narrows and these veinlets progressively merge into the membrane, where they are visible only as faint striæ, and finally disappear. In Rotunosa grandis (Fenn.) the costal vein is slightly submarginal and devoid of transverse veinlets, though towards the node faint transverse striæ can be detected. This condition can be matched elsewhere in tambiniine Tropiduchidæ. As far as American genera are concerned the writer proposes to regard all in which the antennæ are short, with the second joint subglobose, the mesonotum less than 1.5 times as broad as long with the lateral discal carinæ parallel in their basal half, the tegmina thin and subhyaline, with a line of transverse veins between the node and apex of the clavus as belonging to a single subfamily. This group appears to be naturally related to the Old World Tropiduchus.

A key to the new world genera, based on this view, is given below, being modified from the writer's earlier key to Tambiniini (sensu Melichar).

Key to New World Genera of Tropiduchini

(1) (2) Tegmina with a distinct costal area, subequal in width to costal cell, traversed by veinlets to margin for most of length

(2) (1) Tegmina with costal vein marginal, or very narrowly separated, no veinlets to margin along most of length

(3) (4) Vertex twice as long as broad or nearly so

Pseudotangia Metcalf

(4) (3) Vertex relatively shorter

(5) (6) Vertex as long as broad or slightly longer than broad

(6) (5) Vertex broader than long 
(7) (8) Frons with an oblique ridge distally on each side of middle Vanuoides Metcalf

(8) (7) Frons with median carina only ...... Ladella Stàl

(9) (10) Median carina of vertex $\Lambda$-shaped

Tangyria Uhler

(10) (9) Median carina simple, not forked basally Tangella Metcalf and Bruner

(11) (12) Vertex as long as pronotum and mesonotum, more than twice as long as broad

(12) (11) Vertex produced before eyes but not greatly prolonged anteriorly

(13) (14) Vertex with median carina simple to base

Remosa Distant

(14) (13) Vertex with median carina forked basally

Rotunosa Distant

(15) (16) Tegmina with one or no transverse line distad of nodal line

(16) (15) Tegmina with numerous irregular cross-veins in membrane

(17) (18) Vertex distinctly longer than broad ................ (19)

(18) (17) Vertex not longer than broad

(19) (20) Tegmina with a row of subapical areoles distad of nodal line ............................. Athestia Melichar

(20) (19) Tegmina with only apical areoles distad of nodal line, no subapical line ..... Biruga Fennah

(21) (22) Vertex three times as broad as long

Colgorma Kirkaldy

(22) (21) Vertex twice as broad as long, or less

(23) (24) Species more than $7 \mathrm{~mm}$. long; lateral pronotal fields and mesopleurites green

Neorudia Fennah

(24) (23) Species less than $7 \mathrm{~mm}$. long; lateral pronotal fields at margin and a spot on mesopleurites piceous

Amapala Melichar

(25) (26) Vertex with median carina simple, unbranched basally

(26) (25) Vertex with median carina $\lambda$ or $\Lambda$-shaped (33)

(27) (28) Frons ecarinate, sides of vertex parallel

Pelitropis Van Duzee

(28) (27) Frons medially carinate 
(29) (30) Tegmina with M not forked before nodal line; two irregular ranks of transverse veins in membrane distad of nodal line ...... Amaclardea Muir

(30) (29) Tegmina with $\mathrm{M}$ forked before nodal line, more than two ranks of irregular transverse veins in membrane

(31) (32) Media forking near base of tegmen

(32) (31) Media forking near middle of tegmen Monopsis Spinola

Neurotmeta Guérin-Méneville

(33) (34) Vertex with median carina $\lambda$-shaped

(34) (33) Vertex with median carina $\Lambda$-shaped

(35) (36) Vertex longer than broad, directed upward distally Dictyotangia Fennah

(36) (35) Vertex not longer in middle line than broad across base

(37) (38) Vertex as broad as long in middle, lateral margins of frons not meeting lateral margins of vertex, a broad callus on anterior margin of vertex Aripoa Fennah

(38) (37) Vertex broader than long, lateral margins of frons meeting lateral margins of vertex, anterior margin of vertex not callussed

Neotangia Melichar

(39) (40) Submarginal carinæ of pronotum obsolete, represented only by a hump, species about $6 \mathrm{~mm}$. long, tawny, marked with spots of darker brown Tangidia Uhler

(40) (39) Submarginal carinæ of pronotum very sharp, arcuate, species about $8.6 \mathrm{~mm}$. long, uniformly pale green

Dioxyomus Fennah

\section{Ladella Stål}

Stål 1859 Berl. Ent. Zeit. 3: 319. Haplotype, Monopsis pallida Wlk.

\section{Ladella pallida (Wlk.)}

Monopsis pallida Walker 85. List Hom. 2 : 325.

The figures were kindly made by Mr. W. E. China from the type. It is very distinct from the Puerto Rican species identified as Monopsis pallida by Stål and figured 
by Melichar (1914 Ver. Nat. Ver. Brunn 53: 106). The latter species, based on Stål's labelled specimen in the Berlin collection, requires a new name, for which Ladella ståli is now proposed.

Tangella Metcalf and Bruner

Metcalf and Bruner 1930 Psyche 37, 4: 397. Orthotype Tangia kraatzi Stål Berl. Ent. Zeit. 3: 318.

Tangella schaumi (Stål)

Tangia schaumi Stål 1859 Berl. Ent. Zeit. 3: 318.

Male. Length, $5.6 \mathrm{~mm}$.; tegmen, $4.9 \mathrm{~mm}$.

Vertex 3.3 times as broad as long in middle line, medially carinate, carina broad, obsolete at apex, simple at base; frons in middle line 1.5 times as long as broad, a broad callus across basal margin, median carina rather broad. Pronotum with dise large, carinæ stout, two carinæ at each lateral margin between eye and tegula; mesonotum relatively long, lateral carinæ of disc parallel in basal half. Tegmina with costal area broad with about 14 transverse veinlets, nodal line straight, $\mathrm{Sc}+\mathrm{R}$ fork distad of $\mathrm{M}$ fork which is distad of $\mathrm{Cu} 1$ fork, none of these veins forked again before nodal line, membrane with five or six irregular ranks of transverse veinlets, about 16 cells adjoining apical margin between node and apex of clavus. Post-tibiæ with three spines.

Anal segment relatively narrow, each lateral angle produced into a spatulate vertical lobe. झdeagus laterally flattened, upcurved distally, a long spine lying below it on left, bent across to right and curved upward at apex, a group of four processes at apex of ædeagus, the basal process sinuate and spinose, the lateral flattened, symmetrical, pointed distally, the median acicular.

Redescribed from a male taken, along with a nymph, on Jost Van Dyke (Feb. 18, 1944).

\section{Tangyria Uhler}

Uhler 1901 Proc. Ent. Soc. Wash. 4.: 512. Haplotype, Tangyria frontalis Uhl.

Tangyria frontalis Uhler

Uhler 1901 loc. cit.: 512. 
The figures, made by the writer from a female specimen from Port au Prince, Haiti, in the U. S. National Museum bearing Uhler's label, are published to facilitate identification of this genus.

\section{Amaclardea Muir}

Muir 1931 Ann. Mag. Nat. Hist. (10) 7 : 301. Orthotype, Amaclardea gowdeyi Muir.

\section{Amaclardea gowdeyi Muir}

Muir 1931 loc. cit.: 302.

The figures were made by Mr. China from the type. The genus has not yet been reported outside Jamaica.

\section{Neurotmeta Guérin-Méneville}

Guérin-Méneville 1856 Hist. Fisica. Homopt. : 180. Logotype, Neurotmeta sponsa Guérin-Méneville.

Neurotmeta viridis (Wlk.)

Monopsis viridis Walker 1851 List Hom. 2: 325.

Edeagus with two short spines closely approximated and directed caudad lying adpressed to ventral surface, the spine on left slightly curved laterad at apex; apical portion of ædeagus membranous, with a broad opening on right side, an aciculate porrect sclerotised and pigmented spine near dorsal margin directed caudad, a broad tapering process near ventral margin on right, rather flattened, somewhat sclerotised but not pigmented, curved dorsad distally, acute at apex.

The Lesser Antillean representatives of Neurotmeta agree with the species before the writer in all adult structures examined, with the exception of the ædeagal armature, which differs considerably in detail, although conforming to a standard basic pattern of two or three ventral spines along the ventral margin, and from one to four processes directed caudad on the apical membranous portion.

One male and four females and a nymph taken by the writer on Coccoloba uvifera, Virgin Gorda (Feb. 11, 
1944), and one female and two nymphs on the same host, Tortola (Feb. 21, 1944). Walker's type from St. Thomas is a female, and the above assignment requires confirmation.

$$
\text { Colgorma Kirkaldy }
$$

Kirkaldy 1904 Ent. 37 : 279. Orthotype, Achilus dilutus Stål.

$$
\text { Colgorma diluta (Stål) }
$$

Achilus dilutus Stål 1859 Eugen. Resa. 4: 271.

This genus superficially resembles the following, but is readily separated by the tribal character of a relatively long mesonotum. The frons of the type species is longer than broad $(1.3: 1)$ and medially longitudinally tumid rather than carinate.

\section{Tangiopsis Uhler}

Uhler 1901 Proc. Ent. Soc. Wash. 4: 512. Haplotype, Tangiopsis tetrastichus Uhler.

\section{Tangiopsis tetrastichus Uhler}

Uhler 1901 loc. cit.: 513.

The figures are of the Haitian type in the U. S. National Museum, and are given merely to illustrate the differences between Tangiopsis and Colgorma, as no material of either genus is to hand from the Virgin Islands.

Acanalonitde Acanalonia Spinola

Spinola 1839 Ann. Soc. Ent. France. (1) 8: 447. Haplotype, Acanalonia servillei Spin.

\section{Acanalonia depressa Melichar}

Melichar 1901 Ann. K. K. Nat. Hist. Hofmus 16, 3: 190, pl. 1, fig. 6 .

AEdeagus submembranous, not pigmented, a broad fold laterally on each side near base, narrowing distally into a ribbon-like process which recurves at apex and lies below ædeagus to its base, giving off a small S-shaped spine 
laterally, and truncate at apex; remaining portions as figured.

Two males taken by the writer on Jost Van Dyke (Feb. 18, 1944). These specimens differ from Melichar's description and figure only in the profile of the head. According to Dr. Paul Oman, material from St. Thomas and St. Croix differs from the Puerto Rican $A$. brevifrons Muir in being smaller, and having the vertex more sharply declivous, the portion of the head in front of the lateral frontal carinæ shorter, the costal margin of the tegmina more strongly curved and the anterior portion of the apical margin more broadly rounded. The male genitalia of the specimen before the writer are very close to those of $A$. impressa Metc. and Bruner. The species is evidently polytypic and the taxonomic relationship of its members might be most appropriately expressed by regarding brevifrons and impressa as geographical subspecies.

\section{IsSID $\pi$ \\ Thionia Stål}

Stål 1859 Berl. Ent. Zeit. 3: 321. Logotype, Issus longipennis Spinola 1839 Ann. Soc. Ent. France (1) 8: 348.

Thionia argo sp. $\mathrm{n}$.

Male. Length, $5.8 \mathrm{~mm}$. ; tegmen, $4.3 \mathrm{~mm}$. Female. Length, $6.7 \mathrm{~mm}$.; tegmen, $5.0 \mathrm{~mm}$.

Vertex broader than long in middle line (1.5:1), slightly depressed, anteriorly transverse, posteriorly angulately excavate, frons very slightly longer than broad, median carina most prominent in basal half, four callosities on each side near margin, lateral discal carinæ visible only near base where they curve to unite at middle. Posttibiæ bispinose.

Fuscous; all carinæ and margins, parallel oblique striæ on clypeus, minute speckling on frons, vertex, pro- and mesonotum, and sometimes a transverse bar in basal third of frons, and abdominal ventrites testaceous; sides of head on concealed surface behind eyes and a round spot in each lateral field of pronotum piceous. Tegmina 
translucent, testaceous, marbled with fuscous, though not in basal third of corium, three oval spots in cell $R$, a similar spot basally and a fainter spot distally in cell M 3+4 fuscous-piceous. Veins fuscous-piceous, paler in clavus. Transverse veins mostly pallid.

Anal segment of male elongate-rhomboidal, convextruncate at apex, anal foramen near middle. Fdeagus moderately short, tubular, curved upward distally, dorsal margin with an eminence on each side at base and at middle, the latter bearing a short tooth directed caudad, a pair of long spines arising laterally at middle, curved outward, cephalad and finally mesad; ædeagus distally reflected anteriorly in the form of a trough, striate and membranous. Genital styles short and stout, subtriangular, expanding distally; apical process broad, hollowed out on its anterior surface, minutely pointed at apex and with a crescentic plate attached laterally near its base.

Anal segment of female very long distad of anal foramen, deeply rounded at apex.

Nymph with vertex relatively shorter than in adult, the pro- and mesotibiæ distinctly foliate and post-tibiæ fourspined.

Described from four males and seven females and four nymphs taken by the writer on Jost Van Dyke (Feb. 18, 1944). This species may well prove to be closely allied to the Puerto Rican Thionia borinquensis Doz. and the Jamaican Thionia impressa Melichar, though it differs markedly in the coloration of the tegmina. Holotype $\sigma^{\lambda}$ and allotype $q$ at Mus. Comp. Zool. No. 27819.

\section{Flatide}

Parthenormenis gen. nov.

Frons as long as broad, apical margin little shorter than basal, lateral margins shallowly arcuate; vertex obsolete. Pronotum anteriorly roundly convex, posteriorly subangulately concave, a distinct broad callus along anterior margin near middle, a slight median sulcus posteriorly; mesonotum not inflated with median carina indicated only at base, lateral carinæ feebly present 
throughout; post-tibiæ bispinose, abdomen dorsally rounded, not conical. Tegmina moderately expanding distally, costal margin straight distad of middle, apical margin straight, apical angle rounded, sutural angle rectangulate, rather abruptly rounded, costal area slightly narrower than costal cell one third from base, costal veinlets shorter than apical veins, apical veins mostly forked, apical line slightly irregular but distinct, joining costa anteriorly, nodal line indistinguishable, Sc simple to apex, $\mathrm{R}$ forking near middle of tegmen, $\mathrm{M}$ forking slightly basad of $\mathrm{R}$ fork, $\mathrm{Cu} 1$ forking basad of $\mathrm{M}$ fork. Wings with $\mathrm{R}$ simple to apex, $\mathrm{M}$ with two branches, $\mathrm{Cu} 1$ with five branches.

Anal segment of female broadly ovate, indented at apex, anal foramen relatively small. Ovipositor with third valvulæ each armed with nine or ten stout spines in two rows, with a single spine situated on inner face remote from margin.

Type species, Parthenormenis sancte-ursula sp. n.

Parthenormenis sanctæ-ursulæ sp. $\mathrm{n}$.

Female. Length, $6.0 \mathrm{~mm}$; tegmen, $6.2 \mathrm{~mm}$.

Testaceous-yellowish; pronotum and mesonotum clouded fuscous, legs faintly so; abdomen pallid, sclerotised portions of genitalia piceous. Tegmina translucent, brownish, anterior half of costal membrane and transverse veinlets just basad of apical line of cross-veins pallid; base of costal cell, except at margin, and base of clavus deeply infuscate. Veins on corium deeply fuscous, on membrane concolorous. Wings infuscate, veins dark fuscous. Insect in life powdered brownish or pruinose, somewhat variegated.

Ovipositor with third valvulæ armed on posterior margin with a row of five or six stout teeth; basad of this an inner row of two or three teeth, and a single tooth still further basad on inner face.

Described from a single female taken by the writer at 1,000 ft., Tortola (Feb. 20, 1944). Type at Mus. Comp. Zool. No. 27930. The genus, to which at present only this species is referred, is distinguished by having the 
apical margin of the tegmina transverse, not oblique, and the sutural angle boldly, though not sharply, rectangulate, and by the armature of the third valvulæ. It differs from Ormenoides Mel. in the shape of the frons, and from Ormenana Metc. in that of the tegmina.

\section{Melormenis Metcalf}

Metcalf 1938 Bull. Mus. Comp. Zool. 82, 5 : 395. Orthotype, Cicada quadripunctata F.

\section{Melormenis quadripunctata (F.)}

Cicada quadripunctata Fabricius 1794 Ent. Syst. 4: 30.

Ten males and eight females, Jost Van Dyke (Feb. 18, 1944), twenty-six males and sixteen females, Tortola (Feb. 14-17, 19-24, 1944), three males, Virgin Gorda (Feb. 11, 1944).

\section{Petrusa Stål}

Stål 1869 Hem. Fabr. 2: 111; (1866 Hem. Afr.: 237). Haplotype, Cicada marginata Brunnich.

\section{Petrusa marginata (Brunnich)}

Cicada marginata Brunnich 1767, in Linné Syst. Nat. 1 (2) : 710 .

Four males and ten females taken by the writer on Jost Van Dyke (Feb. 18, 1944), six males and seven females, Tortola (Feb. 14-17, 1944), eight males and four females, Virgin Gorda (Feb. 11, 1944). Both color forms are represented in each batch of material. 


\section{Explanation of Plate 4}

1. Ladella pallida (Wlk.) vertex, pronotum and mesonotum.

2. idem, anal segment of male, ventrolateral view.

3. idem, ædeagus, right side.

4. idem, ædeagus, left side.

5. Amaclardea gowdeyi Muir, vertex, pronotum and mesonotum.

6. idem, tegmen.

7. Tangella schaumi (Stål), ædeagus, left side.

8. idem, ædeagus, ventral view.

9. idem, vertex, pronotum and mesonotum.

10. idem, frons and clypeus.

11. idem, tegmen.

12. Neurotmeta viridis (Wlk.), ædeagus, ventral view.

13. idem, ædeagus, right side.

14. Colgorma diluta (Stål) frons and basal part of clypeus.

15. idem, vertex, pronotum and mesonotum.

16. Tangyria frontalis Uhl., vertex, pronotum and mesonotum.

17. Tangiopsis tetrastichus Uhl., vertex, pronotum and mesonotum.

18. Acanalonia depressa Mel, anal segment and ædeagus, left side.

19. idem, head in profile.

20. Thionia argo Fenn., frons and clypeus.

21. idem, vertex and pronotum.

22. idem, tegmen.

23. idem, ædeagus, left side.

24. Parthenormenis sancto-ursula Fenn., tegmen.

25. idem, apical portion of wing. 

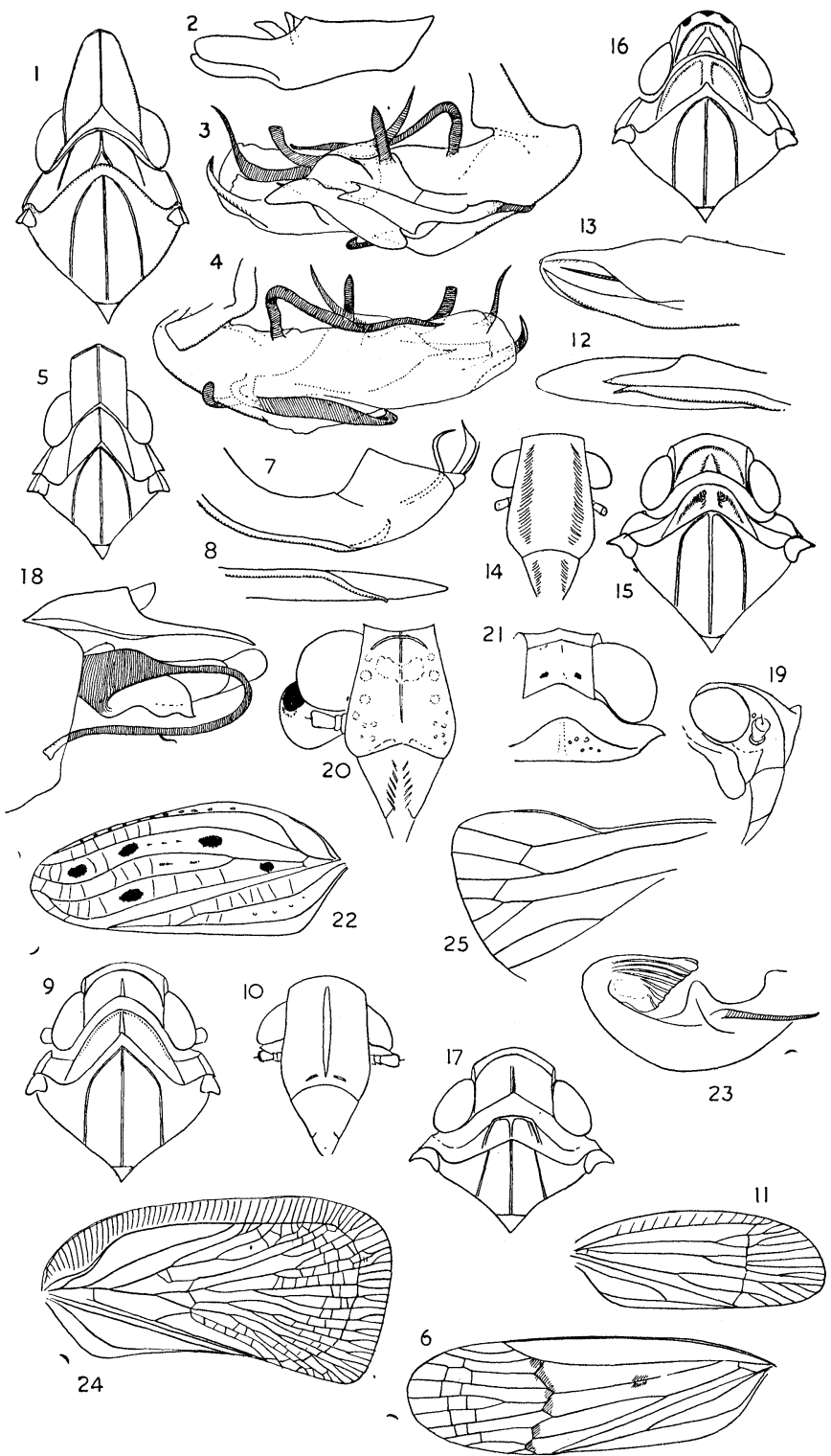

Fennah-Fulgoroidea 

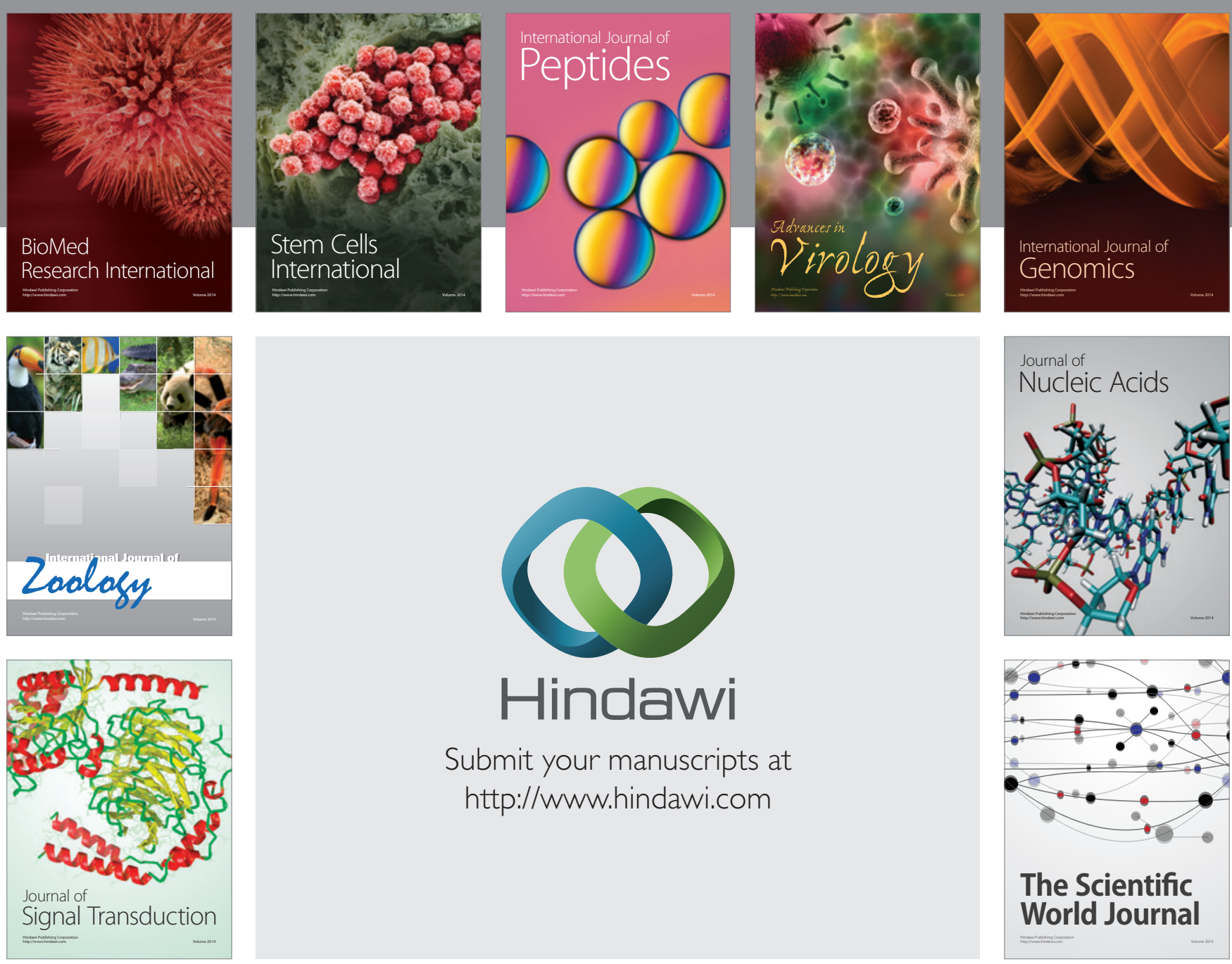

Submit your manuscripts at

http://www.hindawi.com
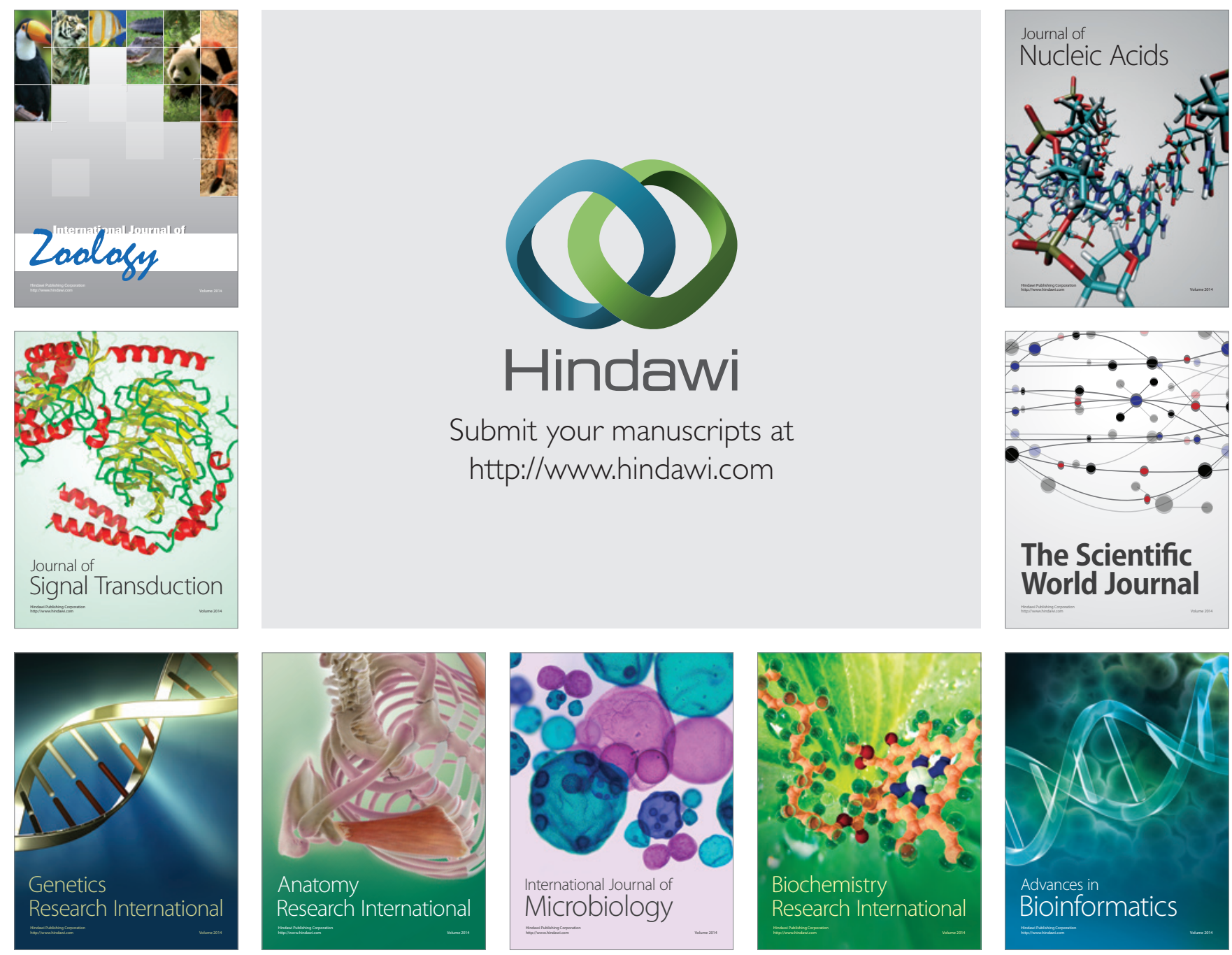

The Scientific World Journal
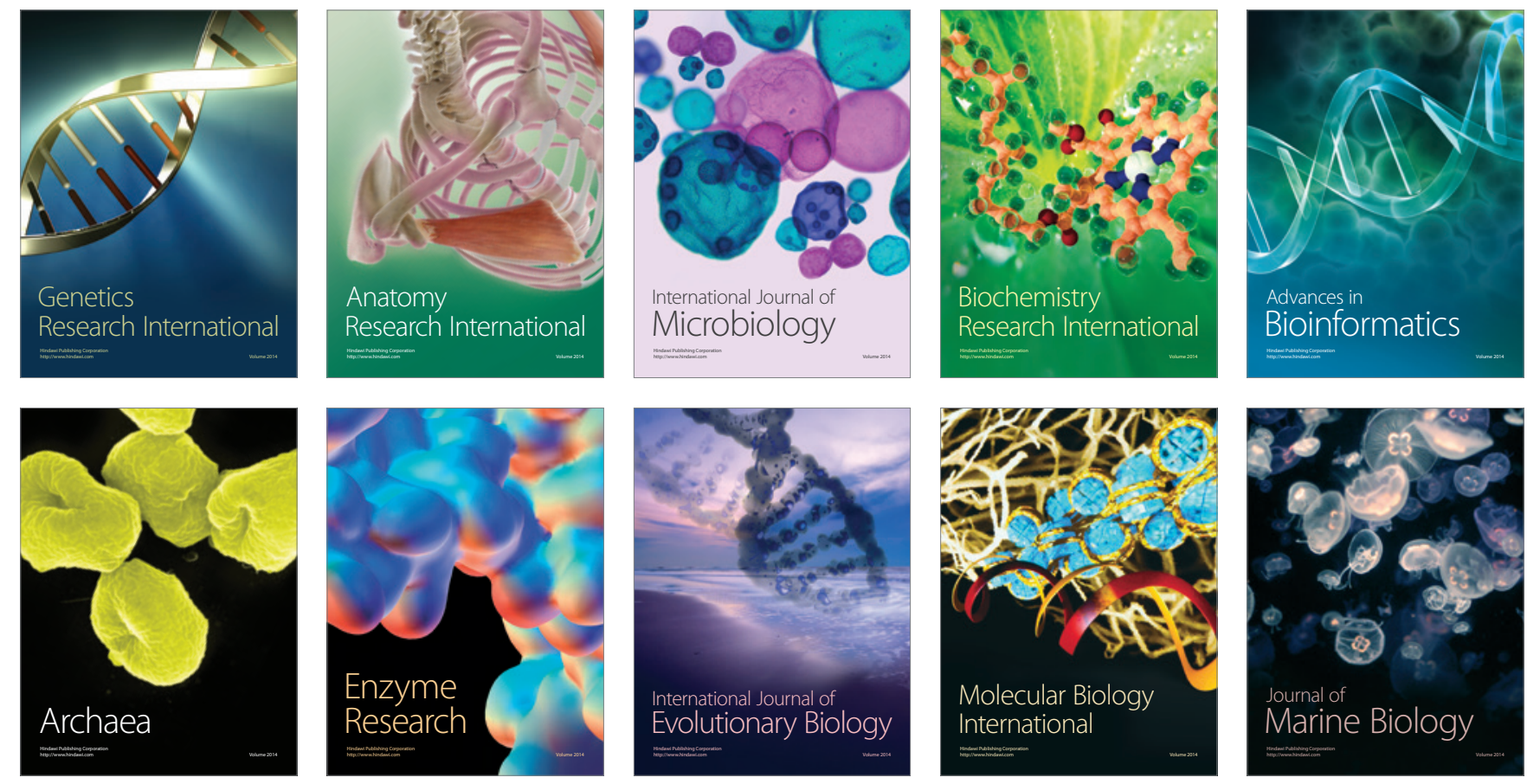